\title{
Synthesis of Human Interleukin-8 by Native Chemical Ligation
}

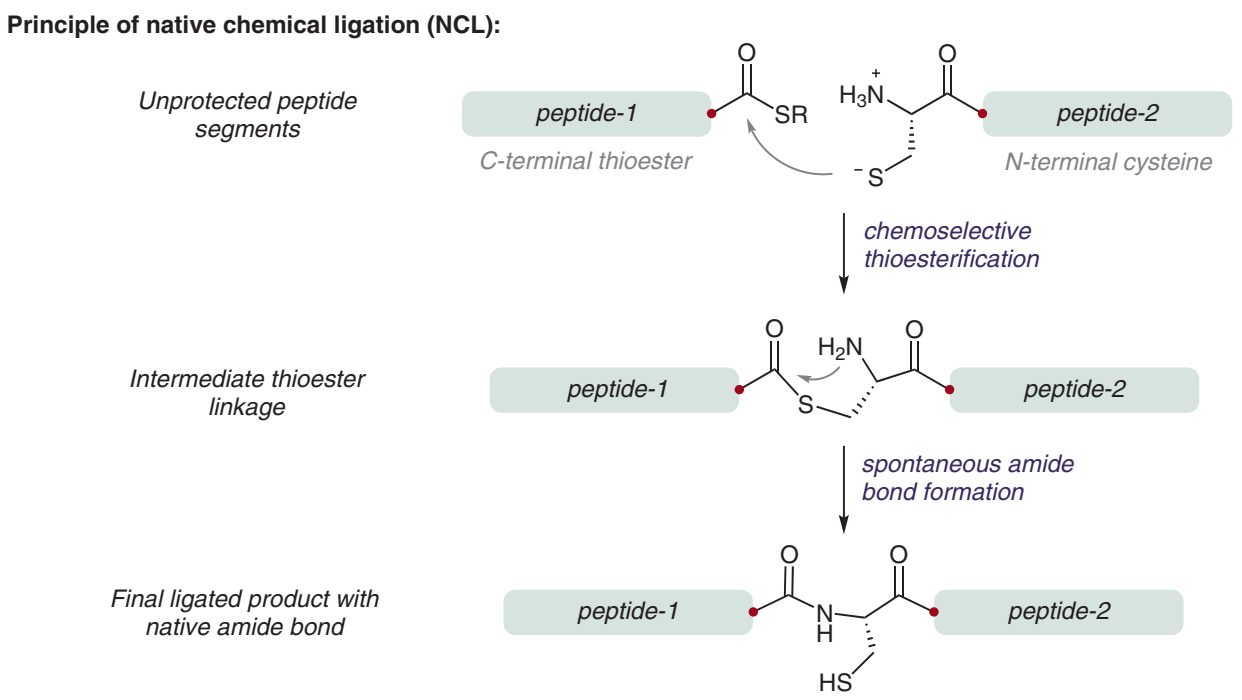

Category

Chemistry in

Medicine and Biology

\section{Key words}

peptide synthesis

native chemical ligation

protein synthesis

human interleukin 8

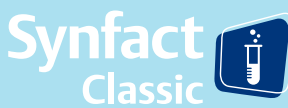

Synthesis of human interleukin 8 (IL-8) via NCL:

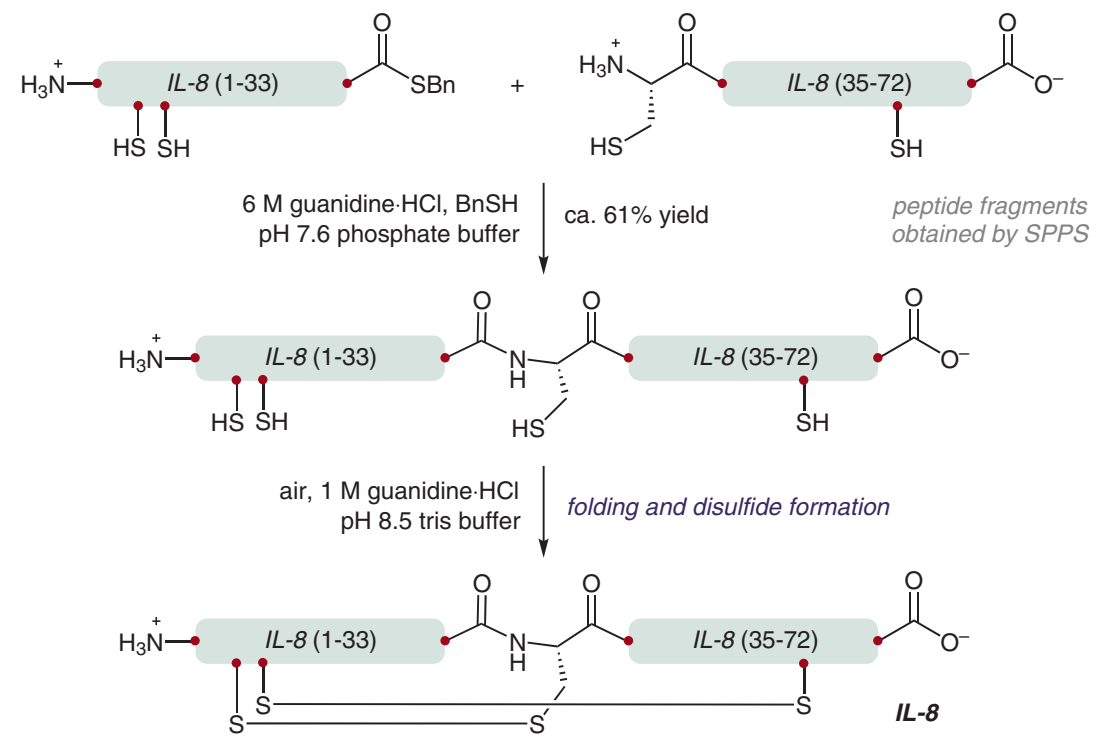

Significance: The realization that unprotected peptide thioesters react chemoselectively with unprotected $\mathrm{N}$-terminal cysteine residues to form amide linkages is an important advancement in protein synthesis. Native Chemical Ligation (NCL) allows synthetic access to proteins of moderate size.
Comment: $\mathrm{NCL}$ proceeds by the formation of an intermediate thioester linkage with cysteine that then spontaneously rearranges to the native amide bond. This strategy was applied to the total chemical synthesis of human interleukin 8 (IL-8), a 72amino acid protein containing four cysteine residues. 